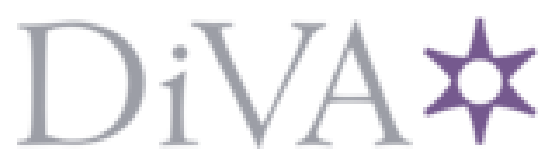

http://www.diva-portal.org

\title{
Postprint
}

This is the accepted version of a paper published in Corporate Governance : The International Journal of Effective Board Performance. This paper has been peer-reviewed but does not include the final publisher proof-corrections or journal pagination.

Citation for the original published paper (version of record):

Eriksson, D. (2016)

A balance model of theoretical sustainability: Framework and propositions.

Corporate Governance : The International Journal of Effective Board Performance, 16(1):

21-34

https://doi.org/10.1108/CG-01-2015-0006

Access to the published version may require subscription.

N.B. When citing this work, cite the original published paper.

Permanent link to this version:

http://urn.kb.se/resolve?urn=urn:nbn:se:hj:diva-34077 


\section{A Balance Model of Theoretical Sustainability - Framework and Propositions}

\section{STRUCTURED ABSTRACT}

Purpose: This describes and discusses a balance model of theoretical business sustainability, in order to leverage the inferior side, so as to enhance performance.

Design/Methodology/approach: A conceptual description and discussion are provided; along with an empirical depiction.

Findings: The empirical illustration presents one organization that embodies the goals of theoretical business sustainability in the marketplace and society.

Research implications: Further research is needed to enhance our understanding of the phenomenon and performance of business sustainability in supply chains.

Practical implications: Findings highlight that there is no justification for practitioners to strive consistently for anything other than theoretical business sustainability, and stakeholders need to push organizations in that direction.

Originality/Value: The paper contributes to our understanding of what should be done and why business sustainability performance should be improved in supply chains.

Keywords: business sustainability, concurrent engineering, corporate social responsibility, supply chain management

Paper type: Conceptual paper 


\section{A Balance Model of Theoretical Sustainability - Framework and Propositions}

\section{Introduction}

A recent increase in concern for the planet earth is evident in both research and practice (e.g., Fassin and Van Rossem, 2009; Aguinis and Glavas, 2012; Winter and Knemeyer, 2013). However, over and over again, we see evidence of companies that fail to meet the moral expectations of their stakeholders (Svensson and Bååth, 2008). People continue to commit actions with an apparent lack of concern for those they affect (Batson and Thompson, 2001; Batson, 2011)

The concept of sustainability has evolved from being concerned mainly with environmental issues to a broader perspective that includes economic, environmental, and social aspects (Asif et al., 2011). Sustainable development may nowadays be defined as development which meets the economic, environmental, and social needs of the present, without compromising the ability of future generations to meet their own needs (WCED, 1987; Elkington, 1997). Corporate Social Responsibility (CSR) is defined similarly as: “...context-specific organizational actions and policies that take into account stakeholders' expectations and the triple bottom line of economic, social, and environmental performance...” (Aguinis and Glavas, 2012, p. 855).

According to Fassin and Van Rossem (2009), the concepts of sustainability and CSR are considered interchangeable by both scholars and practitioners. However, an important distinction between the two concepts is that sustainability has a clear focus on long-term aspects, while CSR (relatively speaking) focuses more on short-term aspects (Bansal and DesJardine, 2014). Corporate efforts that relate to either of the concepts will be referred to here as business sustainability.

Our discussion is limited to a view of theoretical business sustainability, which we define as a utopic state, where the needs of the current generation are met, while simultaneously improving the opportunity for future generations to meet their needs. Our definition and the subsequent balance model of behavioral business sustainability are borrowed and modified from the four hierarchical behavioral levels proposed by Raiborn and Payne (1990).

Here, we apply and classify these into four behavioral levels of business sustainability: (i) theoretical - refers to the fact that behavioral issues of business sustainability may not be attainable, but it is the ideal level of behavior that the marketplace and society should strive to achieve; (ii) practical - behavioral issues of business sustainability can mostly be achieved with diligent efforts; (iii) currently attainable - behavioral issues of business sustainability that are not praised, but accepted by society, reflecting behavior normally exhibited by individuals; and (iv) basic standard -behavioral issues of business sustainability that are acceptable in strict legal terms, but do not comply with the spirit of the law. These will be discussed further in the section on Defining Sustainability.

Morality and ethics often discussed with regard to these behavioral concepts. 'Morality' refers to an immediate, inner sense of right and wrong, while 'ethics' are social constructs of what is rationalized as right and wrong (Eriksson, 2014, p. 5). 


\subsection{Relevance and objective}

Business sustainability research in a supply chain context consists of a plethora of different approaches and focus. Two common distinguishable areas are factors: (i) limiting and (ii) driving business sustainability. Eriksson and Svensson (2015) use three business sustainability factor categories: (i) drivers, (ii) facilitators, and (iii) inhibitors. These are similar to those of Perry and Towers (2013) who address drivers and inhibitors of business sustainability.

We label all factors of business sustainability related to drivers and facilitators (e.g. demand, expectation, and regulation) of business sustainability in the marketplace and society as 'requested'. Factors related to inhibitors (e.g. limitations, restrictions and obstacles) issues of business sustainability are labeled as 'possible'.

Given a topic of business sustainability, what is requested and what is possible may or may not be in balance. This tipping-point of two key areas are under attention here, as we focus on how to move towards enhanced contemporary efforts at business sustainability. Despite the increased attention paid to business sustainability in current research and practice, there are some important issues, of which three will be addressed to provide a relevant foundation for our current topic.

First, research related to supply chain management (SCM) has focused mainly on small-scale empirical investigations and conceptualizations, and lacks a theoretical foundation (Burgess et al., 2006; Ashby et al., 2012). It is argued that researchers are reluctant to move beyond established theories into more innovative territories (Craft, 2012). Aguinis and Glavas (2012) propose that restoring this balance can help to better understand the roles of predictors, mediators, moderators, and outcomes of business sustainability. Moreover, it can help to understand how business sustainability can be built into already demanding workloads and perhaps even enhance work performance, which is related to the next issue.

Second, despite a large body of empirically derived knowledge, it has evidently proven difficult to implement issues of business sustainability in supply chains (Mamic, 2005; Svensson and Bååth, 2008). The manner in which we address the first two areas of insufficient research addresses the third issue of providing relevance to the current paper.

Third, the research focus in the area of business sustainability has been focused on organizational processes, and not the underlying mechanisms that generate corporate behavior in the context of business sustainability (Aguinis and Glavas, 2012; Eriksson and Svensson, 2014).

Subsequently, the objective is to describe and discuss a balance model aimed at moving towards theoretical business sustainability, focusing on the dimensions 'possible' and 'requested'.

We address all three previously mentioned issues: (i) this research draws on a literature review based on a large integrated body of empirical and conceptual research; (ii) we suggest one approach to facilitate the implementation and monitoring of business sustainability issues; and (iii) besides focusing on efforts to improve business sustainability issues, we incorporate a balance model that is based on the underlying mechanisms and thus explains why the various should be implemented and monitored. 
Consequently, we provide a conceptual model based on insights and knowledge from literature on how to improve business sustainability in the marketplace and society. We also provide suggestions on how practitioners may implement state-of-the-art knowledge on business sustainability into their supply chains.

\section{Conceptualization}

The balance model is based on both the literature and empirical demonstration. It draws from different streams of literature in an attempt to understand how sustainability should be pursued in practice. This is sometimes seen as steps towards theory creation, but in this case, it is perhaps best described as 'theory building' (Svensson, 2013, p. 469). We do not, however, claim that we build theory in this particular paper, but follow the logic of abduction (Kovács and Spens, 2005) to combine different ideas in order to more effectively reflect the reality that we study. As such, this research subscribes to the critical realist ontology (Bhaskar, 1978; Danermark et al., 2003) which is both acceptable and common in social science (Aastrup and Halldórsson, 2008; Rotaru et al., 2014; Eriksson, 2015).

\section{Literature Review}

\subsection{Key Elements of Sustainability}

Sixteen elements that drive, facilitate, and/or inhibit sustainability have been identified (Eriksson and Svensson, 2015). The focus here will be on the examples and conceptualizations that make up these elements.

Several stakeholders that are external to supply chains are able to dictate the ways, or reward certain ways, in which business is conducted. Non-governmental organizations (NGO) can coordinate social movements and apply pressure for change (Teegen et al., 2004). Governmental intervention is a major catalyst, and public policy and legislation are critical for sustainable development (Worthington et al., 2008). Consumers create the demand to which companies try to cater, and, by requesting sustainable products and services, they force organizations to rethink their value propositions (Svensson and Wagner, 2012). Other external stakeholders, such as investors and labor organizations, are also associated with increased pressure to improve business sustainability (Teegen et al., 2004; Perry and Towers, 2013).

The competitive strategy of the company is related to consumer demand (Porter, 1996). Lowcost strategies have been linked with increased commoditization, which have proven counteractive to issues of business sustainability as a result of, for example, low supplier interaction (Cousins, 2005) and competitive pressure to reduce costs (Hoejmose et al., 2013a) . Moving from what has mainly been an external stakeholder perspective, we now focus on elements within the supply chain.

Elements internal to the supply chain can be separated into two main groups of managerial and structural, which are not mutually exclusive. Collaboration beyond corporate boundaries in supply chains enables improved business sustainability through, for example, partnership programs (Strand, 2009) and continuous improvements (Fang et al., 2010). Closely related to collaboration is transparency, which may manifest itself in information sharing (Eckerd and Hill, 2012) and traceability (Pagell and Wu, 2009).

In essence, it could be argued that there is a need for a holistic approach to the supply chain when addressing issues of business sustainability (e.g., Ashby et al., 2012), requiring efforts 
such as supplier management (Reuter et al., 2010) and a broad system approach (Björklund et al., 2012). Several issues may emerge, including cultural differences, which may be manifest in communication issues (Fang et al., 2010) and regulatory differences (Abbasi and Nilsson, 2012).

Moreover, differences in power between actors can hinder a 'weak' party attempting to align the supply chain with its own efforts at business sustainability (e.g., Spence and Bourlakis, 2009; Hoejmose et al., 2013b). One long-term approach for overcoming several of these issues includes vertical integration, which can mediate the discrepancy between areas of responsibility and ownership (Faruk et al., 2002). Finally, the length of the chain, both geographically (e.g., Wisner and Tan, 2000; Carrington et al., 2010) and in terms of the number of tiers (e.g., Mares, 2010; Perry and Towers, 2013), hinders the implementation and monitoring of business sustainability in supply chains.

The third group of elements resides primarily within a focal company. A prevalent element is managerial support, which is also often mentioned in quality management (e.g., Womack and Jones, 1996; Carter and Jennings, 2002). Managers are, among other things, responsible for economic allocation (Côté et al., 2008). Financial distribution can help promote an internal consensus towards business sustainability (Mamic, 2005) and is evident in both a sound organizational culture (Carter and Rogers, 2008) and a reduction of silo mentality (Lee and Kim, 2009).

Besides the allocation of funds, companies also need to understand that performance is not only measured with financial KPIs (Carter and Rogers, 2008), and that business sustainability goals need to be linked to corporate strategy in performance measurements (Pagell and $\mathrm{Wu}$, 2009). In relation to measuring performance, it is important that employees be held accountable for their decisions (Reuter et al., 2012). It has been suggested that incentives through reward systems (Pagell and $\mathrm{Wu}, 2009$ ), that can also be enforced through corporate culture (Reuter et al., 2012), can help guide activities towards improved business sustainability.

Finally, education is considered an important element for two reasons. Firstly, education helps inform employees of the effects of their actions (e.g., Mamic, 2005), and secondly improve their sensitivity and appreciation for issues of business sustainability (Cambra-Fierro and Ruiz-Benítez, 2011).

It is apparent that several of the points addressed above are related to issues that cannot be resolved overnight, but are parts of strategic, tactical, and operational decisions. There is therefore a need to begin the process at the drawing board. Not only cost structures are determined largely during new product development (Appelqvist et al., 2004), but also the future supply chain needed to transform raw materials into final products in the hands of consumers (Crippa et al., 2010). Next, a concept aimed at leveraging the strategic capabilities of the supply chain and aligning new product development with SCM is presented, namely concurrent engineering.

\subsection{Concurrent Engineering}

This is an approach centered around the notion that new product development and SCM need to be aligned, and that management directions are influenced by decisions made in the early stages of new product development (e.g., Hong et al., 2009; Khan and Creazza, 2009). New product development that is undertaken without consideration of the capabilities of the supply 
chain can result in products that are difficult to produce and do not provide the specified quality. Concurrent engineering has been linked to potential competitive advantages through a reduction of time-to-market where demand is volatile (Gunasekaran, 1998; Khan et al., 2012). Products are designed with input from all concerned stakeholders, especially the consumers who ultimately determine product success (Gunasekaran, 1998). While the approach often focuses on intra-organizational aspects (Hilletofth and Eriksson, 2011), it has been shown how members of the supply chain play a vital role from the early stages of new product development to the point of (potential) sales (Eriksson et al., 2013a).

Business sustainability is nowadays considered an opportunity for strategic differentiation and competitive advantage (e.g., Loureiro et al., 2012; Soosay et al., 2012; Cruz, 2013). Recently, Gmelin and Seuring (2014, p. 6) concluded that "product life-cycle management highly contributes to a new product development directed toward sustainable attributes". Despite not mentioning concurrent engineering, Asif et al. (2011, p. 361) state that: “...it is important to ensure that integration [of vision and strategies] takes place at all organizational levels, vertically and horizontally...”, and the "...fit among organizational activities at the tactical and operational level is necessary, since the alternative is unintegrated, stand-alone processes that create confusion for employees and, invariably, ineffective and inefficient use of resources...”. Accordingly, Høgevold (2011) concludes that sustainable aspects integrated into early product development are an established part of moving toward sustainable business operations.

So far, the emerging framework has focused on how SCM and new product development are related to business sustainability. The next part of the framework is concerned with the perceived moral responsibility among stakeholders, with regard to the supply chain.

\subsection{Moral Responsibility in Supply Chains}

SCM is often referred to as the management of financial, economic, and material flows across the supply chain (e.g., Mentzer et al., 2001). Eriksson et al. (2013c) propose that moral responsibility should also be considered a flow in the chain. Accordingly, disrupting the flow of moral responsibility is may lead to moral disengagement (Eriksson, 2014). Such disengagement consists of eight psychological mechanisms, which individuals might use to self-sanction behavior that they would normally consider immoral (Bandura et al., 1996; Bandura, 1999).

Through a reduction of practices associated with SCM that cause moral disengagement, it is possible to raise the perceived moral responsibility of stakeholders, and consequently improve business sustainability (Eriksson and Svensson, 2014). These practices are related to both the structure and management of the supply chain (Eriksson et al., 2013b). Moral disengagement can explain why people behave immorally, and SCM provides the context in which moral disengagement occurs. SCM can have a deterministic impact on stakeholders, causing moral disengagement, and moral engagement can have a voluntarist affect on how the supply chain is managed. Considered together, it can also be described as reciprocal determinism (Bandura, 1978, p. 346), which may hold a key to a better understanding of how business sustainability should be improved.

Managerial issues include companies needing to acknowledge full responsibility for their activities across the entire supply chain, and employees not only being encouraged to conform to corporate guidelines, but also held accountable for not following them. Structural issues that are important in the supply chain include improved traceability (e.g. no aggregation of 
raw-material from several sources) and a reduction of organizational entities, preferably vertical integration (Eriksson and Svensson, 2015).

Young (2004) suggests that it is impossible to address all the effects of all the actions in which an individual takes part and/or supports in daily life, through, for example, work and consumption. She argues that the decision on what to improve should be based on connection, power, and privilege. This in turn implies that responsibility is first and foremost taken for situations that one can influence, where one has the ability to make an impact, and where the welfare of one comes at the price of harm of others (e.g. luxury products produced by underpaid workers in a dangerous environment).

\section{Defining Theoretical Sustainability}

\subsection{Four Behavioral Levels of Business Sustainability}

Before presenting our balance model of theoretical business sustainability, we introduce a model that explains different standards of behavior.

Raiborn and Payne (1990) present four standards of ethical behavior, using a hierarchy founded in cost accounting. The highest level is 'theoretical'. While it might not be attainable, it is the ideal that society should strive to achieve. The second highest level is 'practical', which, with diligent effort, can be achieved most of the time. The third level is 'currently attainable', and behavior that is not praised, but accepted by society, falls into this classification. This is the behavior normally exhibited by individuals. The fourth and final level is 'basic standard', which refers to behavior which is acceptable according to the regulations, but does not comply with the spirit of the law.

The theoretical standard of business sustainability should reflect a level of business sustainability that requires ongoing improvement. This level entails practices that meet our needs, but also ensure that future generations are able to meet their needs as proposed by WCED (1987). At this level, the current generation is, in a worst-case future scenario, forced to go beyond a zero impact on the Earth's life- and eco-systems.

We propose the following definition of theoretical business sustainability: meeting the economic, environmental, and social needs of the present, while simultaneously improving the ability of future generations to meet their own needs.

The practical standard reflects extreme diligence in the context of business sustainability. The behavior is attainable through dedication. The currently attainable standard reflects sustainable development that the average stakeholder normally exhibits and requests. Finally, the basic standard of business sustainability complies with regulatory needs, but does so without considering the intent of the law. Arrangements may be made to avoid both legislation and accountability for non-compliance.

\subsection{Leveraging the Inferior Side}

Drawing on the previous literature presented and discussed above, we can isolate two important facets of improved business sustainability in supply chains, namely: (i) what is possible, and (ii) what is requested. The idea is centered on the notion that what is possible and what is requested need to move continuously towards theoretical business sustainability. It does not matter how much stakeholders desire and strive towards business sustainability, if the technology is inferior and unable to perform accordingly. Analogously, it does not matter how sustainable it is possible to be, if stakeholders are not willing to pay, or interested in such 
offerings. The inferior side needs to be leveraged. The distinctions between the behavioral standards of business sustainability clearly address issues of feasibility and what stakeholders accept. The behavioral standards of business sustainability can move slowly towards theoretical business sustainability by increasing the pressure for sustainable practices and for driving the necessary technological advancements.

The sustainable capabilities of a supply chain are related to how effectively issues of business sustainability are integrated into the strategy (e.g., Porter and Kramer, 2011; Walker and Jones, 2012). Business sustainability, in turn, is related to SCM (e.g., Lee and Kim, 2009; Ashby et al., 2012). One way to align strategy, NPD, and SCM is through CE. The supply chain can thus improve the business sustainability performance of the product, but the product itself can also be designed to improve the business sustainability performance of the supply chain. Consequently, what was originally theoretical business sustainability, can become practical business sustainability, what was practical business sustainability can become currently attainable business sustainability, and what was currently attainable business sustainability can become basic business sustainability.

The requested business sustainability, on the other hand, also needs to be improved. Focusing on moral disengagement, it is possible to manage the chain in such a manner that stakeholders' sense of moral responsibility increases (Eriksson and Svensson, 2014). Stakeholders that become more concerned with business sustainability can request more sustainable efforts from the organization. For example, consumers vote with their wallet (Svensson and Wagner, 2012), legislators dictate the rules business operation (Fang et al., 2010), and employees demand that organizations improve business sustainability (Carter and Easton, 2011). Consequently, pressure to improve business sustainability raises the expectations from various stakeholders of what constitutes basic, currently attainable, practical, and theoretical business sustainability.

The two approaches to moving what is possible and what is requested closer to theoretical business sustainability are depicted in Figure 1, which shows the logic of the balance model based on three illustrative scenarios (i.e., A, B, and C).

\section{Insert Figure 1 about here}

Scenario A in Figure 1 reflects a situation of business sustainability where stakeholders request less than is actually possible. In this situation, it is not necessary for technological improvements to enhance business sustainability. Rather, it is important to raise what stakeholders request, so that they are convinced to invest in more sustainable practices. This state is commonly addressed in research, for example, consumers say that they want shoes produced in a sustainable manner, but are not willing to pay for this (Feldman and VasquezParraga, 2013).

Scenario B in Figure 1 reflects a converse situation of business sustainability, in which stakeholders request a level of sustainability that is currently not possible to deliver. It is thus an engineering challenge to improve business sustainability. Sustainability performance initiatives, stemming from stakeholder demands for improvement, also be found in the literature. For example, Alkaya and Demirer (2014) outline the reduced environmental impact from a Turkish fabric manufacturer. 
Scenario $C$ in Figure 1 at first sight reflects an ideal situation of business sustainability where stakeholder requests are met the greatest possible extent. However, this may in be the worst scenario, namely that what is possible and what is requested have reached equilibrium. As such, there is no incentive to initiate a movement towards theoretical business sustainability. If there is no stakeholder demand for improvement, or if there are no value propositions that need to be marketed, the development does not move towards theoretical business sustainability, and there is a stalemate of the four standards of behavioral business sustainability. In recent years, several examples of how a broken stalemate led to improvements are available, with companies such as Gina $\operatorname{Tricot}^{1}, \operatorname{Lego}^{2}$ and Patagonia ${ }^{3}$.

\section{Empirical Illustration}

We have identified one organization that embodies the goals towards theoretical business sustainability, namely the smartphone manufacturer Fairphone. This company was founded in 2010 as a campaign aimed at increasing awareness of the abuses in the electronics supply chain.

Fairphone was initially intended to be run as a non-governmental organization, but they decided that they could have a more positive impact if they conducted business as a for-profit company. However, in their mission statement, the company establishes that their main goal has always been, and will always be to deal with social issues. Fairphone sees no value in profits alone, and any profits should be invested in raising social welfare.

The company has been included here for illustrative purposes. The information presented is compiled from secondary data obtained from the company's homepage (www.fairphone.com). The company exhibits a strong dedication towards transparency, with regard to both their supply chain, and the views and perceptions of their employees and managers. Information is available on their website and blog. In a blog post, Joe Mier, the community manager, shows the unconventional nature of the company's philosophy, writing as follows:

"it became clear to me that producing and consuming electronics is at best lazy, at worst unethical".

"End-of-life" and "conflict minerals" are two key focus areas for Fairphone. A notorious concern for the electronic industry is waste management. Waste from this industry (e-waste) is difficult for developing countries to treat and handle. Destructive treatment is commonly used to recover metals (e.g., burning off plastic materials). Currently, for each phone the company produces, they recycle three that are no longer wanted by their owners. Phones that are removed from the market are disassembled and shipped to modern treatment/recycling plants in Europe, where metals are extracted and melted. This is part of a quest to reach a netpositive effect on sustainable development/Earth's life and eco-systems.

Tin, tungsten, tantalum, and gold are examples of conflict minerals, which are mined under conditions where workers face violence and armed guards. Armed forces also try to capitalize on these minerals to support their own non-democratic agenda. Mining these minerals can have a significant impact on the local environment.

\footnotetext{
${ }^{1}$ http://www.ginatricot.com/eu/en/csr/blog/1601/NO+MORE+ANGORA

${ }^{2}$ http://www.theguardian.com/environment/2014/oct/09/lego-ends-shell-partnership-following-greenpeacecampaign

${ }^{3}$ http://www.thecleanestline.com/2015/08/petas-wool-video.html
} 
"The use of chemicals in the activity of mining or as a by-product of the extracted material may often cause erosion and contamination of both the local soil and water systems. These are all detrimental impacts of mining as regards the local community."

Following the extraction of conflict minerals in the Democratic Republic of Congo, large volumes are smuggled to Rwanda and Uganda, from where they are shipped to the Far East. The minerals pass through the hands of several middlemen, making it hard to trace the origin. Also, the minerals are melted and mixed with others from around the world.

Fairphone is engaged in projects promoting the use of conflict-free minerals and is transparent in its online dialogue about their progress. The company showcases examples of success, but also areas that are still problematic and how it addresses them. The company is not content with its current environmental impact and admits to having:

"even bigger plans for a larger array of other precious materials in the very near future, aiming to save the environment tons of toxic waste".

The communication is personal and tells a story of how the company wants to start a social movement. One of Fairphone's CE-related issues concerns the lifetime of their product:

"To design for longevity, the designers' primary concern needs to be to create a well-crafted product that the user will not want, or need to, throw away. When it breaks, the user can fix or upgrade the product themselves."

Moreover, they focus on design for disassembly, so that materials can be easily recovered when the phone is no longer in use.

The company was founded by the current CEO as an awareness project. A case can be made that the company is a good model of a sustainability awareness campaign that happens to focus on mobile phones. Furthermore, Fairphone openly discusses technological challenges towards producing a product with a positive sustainable impact. The company is an excellent practical illustration of the balance model, and shows that what is currently practical can also be seen as a challenge for the future and not a state in which to be content. Founder/CEO Bas van Abel makes a comment with regard to the stale-mate and the need to constantly push for better solutions:

"Even if we couldn't achieve perfection with our first attempt, we knew we could try and do better than the status quo and help hold the entire industry to a higher standard...”

\section{Implications}

The overreaching implication of the balance model is that there is no need to accept anything other than a constant striving for theoretical business sustainability. However, it appears that corporations are still destroying their resource base faster than the environment can recover, naturally or artificially (Walker and Laplume, 2014).

The conceptual description and explanation provided in previous sections highlights the need for both scholars and practitioners to strive for improved knowledge on how to implement and 
monitor changes with regard to business sustainability. The description and explanation provided also motivates a stream of research investigating how theories can help to understand why otherwise decent people seem to be willing to take part in and/or support acts with the most heinous consequences (cf. Bandura et al., 1996). Practitioners also need to apply pressure on both researchers to better explain and predict business sustainability phenomena, and on stakeholders to improve and request more of the organizations.

The major implication is related to society at large. If we step back from the current focus and reflect on the bigger picture, the potential disasters lurking in anthropogenic climate change, anti-democratic countries that are allowed to invade autonomous ones, and more and more people falling below the poverty line, it is painfully obvious that we cannot remain content with a business state that tries to achieve anything less than the theoretical business sustainability. The implications from Young (2004) also reveal that there is always more to do, but while she focuses on individual action based on possibilities and responsibilities, we focus on where and how is important for both individuals and organizations to take responsibility.

\section{Conclusions}

Theoretical business sustainability not only appears utopic, it is an unattainable behavioral standard demanding progression. Nonetheless, we argue that this approach is the only one that continuously forces us to move towards enhanced business sustainability performance and a better future.

This current paper contributes to our understanding of what should be done and why, so as to improve business sustainability performance in supply chains in three ways: (i) we draw on and compile knowledge from a large pool of empirical and conceptual papers; (ii) we are the first to apply what is, to the best of our knowledge and according to recent reviews (e.g., Aguinis and Glavas, 2012; Eriksson and Svensson, 2015), a theory that explains generative mechanisms (Rotaru et al., 2014) in the area of sustainability and CSR in SCM; and (iii) we also suggest a route that can help in implementing and monitoring issues of business sustainability, including both technical and psychological aspects. Our contribution is centered on the balance model consisting of request and possibility of leveraging the inferior side of production.

Recently, Walker and Laplume (2014) focus on how collective stakeholder influences might be necessary to create sufficient pressure to bring about vital change. Such ideas are an important complement to the balance model.

The case of Fairphone provides an excellent empirical illustration of how a company does not need to accept the current situation and that it is always possible to do more. Fairphone has chosen an approach that is unconventional and unlikely to be broadly adopted. While they advocate economic business sustainability for production markets, they are run as a non-profit organization with social values at the heart of their mission statement. Therefore, while they showcase an attempt at a sustainable business model, the business sustainability of the company is still to be determined. The real challenge revolves around whether it will survive over time in the marketplace.

Inevitably, our description and discussion the concept of theoretical business sustainability and the balance model contain certain shortcomings. For example, we only suggest concurrent engineering to implement and monitor business sustainability performance. Other approaches 
exist, such as closed-loop supply chains (Abbasi and Nilsson, 2012) and design for environment (Faruk et al., 2002). The idea presented in this paper, however, has centered on improving what is possible through engineering and managerial advancements, not by only using concurrent engineering. Examples include improved refrigeration systems in stores (Dos Santos, 2011), and increased managerial involvement in key issues (Carter and Jennings, 2002). Concurrent engineering should mainly be seen as just one suggestion for implementing and monitoring business sustainability performance.

Complementary approaches to assessing business sustainability performance, which fit into the category of pushing forward what is possible, are both needed and welcome. Even so, we see two compelling reasons to go ahead and share our ideas. Firstly, the large pool of literature used and the theoretical weight of the concepts applied, ensure relevance of the topic. Secondly, the importance of business sustainability performance in supply chains is of great, even fundamental importance, and new ideas need to be shared.

\section{References}

Aastrup, J. and Halldórsson, Á., (2008). "Epistemological role of case studies in logistics: A critical realist perspective", International Journal of Physical Distribution \& Logistics Management, Vol. 38 No. 10, pp. 746-763.

Abbasi, M. and Nilsson, F., (2012). "Themes and challenges in making supply chains environmentally sustainable", Supply Chain Management: An International Journal, Vol. 17 No. 5, pp. 517-530.

Aguinis, H. and Glavas, A., (2012). "What We Know and Don't Know About Corporate Social Responsibility: A Review and Research Agenda", Journal of Management, Vol. 38 No. 4, pp. 932-968.

Alkaya, E. and Demirer, G.N., (2014). "Sustainable textile production: a case study from a woven fabric manufacturing mill in Turkey", Journal of Cleaner Production, Vol. 65 No., pp. 595-603.

Appelqvist, P., Lehtonen, J.-M. and Kokkonen, J., (2004). "Modelling in product and supply chain design: literature survey and case study", Journal of Manufacturing Technology Management, Vol. 15 No. 7, pp. 675-686.

Ashby, A., Leat, M. and Hudson-Smith, M., (2012). "Making connections: a review of supply chain management and sustainability literature", Supply Chain Management: An International Journal, Vol. 17 No. 5, pp. 497-516.

Asif, M., Searcy, C., Zutshi, A. and Ahmad, N., (2011). "An integrated management systems approach to corporate sustainability", European Business Review, Vol. 23 No. 4, pp. 353-367.

Bandura, A., (1978). "The Self System in Reciprocal Determinism", American Psychologist, Vol. 33 No. 4, pp. 344-358.

Bandura, A., (1999). "Moral Disengagement in the Perpetration of Inhumanities", Personality and Social Psychology Review, Vol. 3 No. 3, pp. 193-209.

Bandura, A., Barbaranelli, C., Caprara, G.V. and Pastorelli, C., (1996). "Mechanisms of Moral Dissengagement in the Exercise of Moral Agency", Journal of Personality and Social Psychology, Vol. 71 No. 2, pp. 364-374.

Bansal, P. and Desjardine, M.R., (2014). "Business sustainability: It is about time", Strategic Organization, Vol. 12 No. 1, pp. 70-78.

Batson, C.D., (2011). "What's Wrong with Morality?", Emotion Review, Vol. 3 No. 3, pp. 230-236. 
Batson, C.D. and Thompson, E.R., (2001). "Why Don't Moral People Act Morally? Motivational Considerations", Current Directions in Psychological Science, Vol. 10 No. 2, pp. 54-57.

Bhaskar, R., (1978). A realist theory of science, Harvester Press, Hassocks, UK.

Björklund, M., Martinsen, U. and Abrahamsson, M., (2012). "Performance measurements in the greening of supply chains", Supply Chain Management: An International Journal, Vol. 17 No. 1, pp. 29-39.

Burgess, K., Prakash, S.J. and Rana, K., (2006). "Supply chain management: a structured literature review and implications for future research", International Journal of Operations \& Production Management, Vol. 26 No. 7, pp. 703-729.

Cambra-Fierro, J. and Ruiz-Benítez, R., (2011). "Sustainable business practices in Spain: a two-case study", European Business Review, Vol. 23 No. 4, pp. 401-412.

Carrington, M.J., Neville, B.A. and Whitwell, G.J., (2010). "Why Ethical Consumers Don't Walk Their Talk: Towards a Framework for Understanding the Gap Between the Ethical Purchase Intentions and Actual Buying Behaviour of Ethically Minded Consumers", Journal of Business Ethics, Vol. 97 No. 1, pp. 139-158.

Carter, C.R. and Easton, P.L., (2011). "Sustainable supply chain management: evolution and future directions", International Journal of Physical Distribution \& Logistics Management, Vol. 41 No. 1, pp. 46-62.

Carter, C.R. and Jennings, M.M., (2002). "Social responsibility and supply chain relationships", Transportation Research Part E, Vol. 38 No. 1, pp. 37-52.

Carter, C.R. and Rogers, D.S., (2008). "A framework of sustainable supply chain management: moving toward new theory", International Journal of Physical Distribution \& Logistics Management, Vol. 38 No. 5, pp. 360-387.

Cousins, P.D., (2005). "The alignment of appropriate firm and supply strategies for competitive advantage", International Journal of Operations \& Production Management, Vol. 25 No. 5, pp. 403-428.

Craft, J.L., (2012). "A Review of the Empirical Ethical Decision-Making Literature: 20042011", Journal of Business Ethics, Vol. 117 No. 2, pp. 221-259.

Crippa, R., Larghi, L., Pero, M. and Sianesi, A., (2010). "The impact of new product introduction on supply chain ability to match supply and demand", International Journal of Engineering, Science and Technology, Vol. 2 No. 9, pp. 83-93.

Cruz, J.M., (2013). "Modeling the relationship of globalized supply chains and corporate social responsibility", Journal of Cleaner Production, Vol. 56 No. c, pp. 73-85.

Côté, R.P., Lopez, J., Marche, S., Perron, G.M. and Wright, R., (2008). "Influences, practices and opportunities for environmental supply chain management in Nova Scotia SMEs", Journal of Cleaner Production, Vol. 16 No. 15, pp. 1561-1570.

Danermark, B., Ekström, M., Jakobsen, L. and Karlsson, J., (2003). Att förklara samhället, Studentlitteratur, Lund, Sweden.

Dos Santos, M.a.O., (2011). "Minimizing the business impact on the natural environment: A case study of Woolworths South Africa", European Business Review, Vol. 23 No. 4, pp. 384-391.

Eckerd, S. and Hill, J.A., (2012). "The buyer-supplier social contract: information sharing as a deterrent to unethical behaviors", International Journal of Operations \& Production Management, Vol. 32 No. 2, pp. 238-255.

Elkington, J., (1997). Cannibals with Forks: The Triple Bottom Line of the 21st Century Business, New Society, Stony Creek, CT.

Eriksson, D., (2014). Moral (De)coupling: Moral Disengagement and Supply Chain Management, PhD Thesis, University of Borås, Borås, Sweden. 
Eriksson, D., (2015). "Lessons on Knowledge Creation in Supply Chain Management", European Business Review, Vol. No., pp. 346-368.

Eriksson, D., Hilletofth, P. and Hilmola, O.-P., (2013a). "Creating value through wholesaler and retailer interface", Industrial Management \& Data Systems, Vol. 113 No. 8, pp. 1169-1188.

Eriksson, D., Hilletofth, P. and Hilmola, O.-P., (2013b). "Linking moral disengagement to supply chain practices", World Review of Intermodal Transportation Research, Vol. 4 No. 2/3, pp. 207-225.

Eriksson, D., Hilletofth, P. and Hilmola, O.-P., (2013c). "Supply chain configuration and moral disengagement", International Journal of Procurement Management, Vol. 6 No. 6, pp. 718-736.

Eriksson, D. and Svensson, G., (2014). "The Process of Responsibility, Decoupling Point, and Disengagement of Moral and Social Responsibility in Supply Chains: Empirical Findings and Prescriptive Thoughts", Journal of Business Ethics, Vol. No., pp. 1-18.

Eriksson, D. and Svensson, G., (2015). "Elements affecting social responsibility in supply chains", Supply Chain Management: An International Journal, Vol. 20 No. 5, pp. 101122.

Fang, T., Gunterberg, C. and Larsson, E., (2010). "Sourcing in an Increasingly Expensive China: Four Swedish Cases", Journal of Business Ethics, Vol. 97 No. 1, pp. 119-138.

Faruk, A.C., Lamming, R.D., Cousins, P.D. and Bowen, F.E., (2002). "Analyzing, Mapping, and Managing Environmental Impacts along Supply Chains", Journal of Industrial Ecology, Vol. 5 No. 2, pp. 13-36.

Fassin, Y. and Van Rossem, A., (2009). "Corporate Governance in the Debate on CSR and Ethics: Sensemaking of Social Issues in Management by Authorities and CEOs", Corporate Governance: An International Review, Vol. 17 No. 5, pp. 573-593.

Feldman, P.M. and Vasquez-Parraga, A.Z., (2013). "Consumer social responses to CSR initiatives versus corporate abilities", Journal of Consumer Marketing, Vol. 30 No. 2, pp. 100-111.

Gmelin, H. and Seuring, S., (2014). "Determinants of a sustainable new product development", Journal of Cleaner Production, Vol. 69 No., pp. 1-9.

Gunasekaran, A., (1998). "Agile manufacturing: enablers and an implementation framework", International Journal of Production Research, Vol. 36 No. 5, pp. 1223-1247.

Hilletofth, P. and Eriksson, D., (2011). "Coordinating new product development with supply chain management", Industrial Management \& Data Systems, Vol. 111 No. 2, pp. 264-281.

Hoejmose, S., Brammer, S. and Millington, A., (2013a). "An empirical examination of the relationship between business strategy and socially responsible supply chain management", International Journal of Operations \& Production Management, Vol. 33 No. 5, pp. 589-621.

Hoejmose, S.U., Johanne, G. and Millington, A., (2013b). "Socially responsible supply chains: power asymmetries and joint dependence", Supply Chain Management: An International Journal, Vol. 18 No. 3, pp. 277-291.

Hong, P., Kwon, H.-B. and Roh, J.J., (2009). "Implementation of strategic green orientation in supply chain: An empirical study of manufacturing firms", European Journal of Innovation Management, Vol. 12 No. 4, pp. 512-532.

Høgevold, N.M., (2011). "A corporate effort towards a sustainable business model: A case study from the Norwegian furniture industry", European Business Review, Vol. 23 No. 4, pp. 392-400. 
Khan, O., Christopher, M. and Creazza, A., (2012). "Aligning product design with the supply chain: a case study", Supply Chain Management: An International Journal, Vol. 17 No. 3, pp. 323-336.

Khan, O. and Creazza, A., (2009). "Managing the Product Design-Supply Chain Interface: Towards a Roadmap to the 'Design Centric Business'", International Journal of Physical Distribution \& Logistics Management, Vol. 39 No. 4, pp. 301-319.

Kovács, G. and Spens, K.M., (2005). "Abductive Reasoning in Logistics Research", International Journal of Physical Distribution \& Logistics Management, Vol. 35 No. 2, pp. 132-144.

Lee, K.-H. and Kim, J.-W., (2009). "Current status of CSR in the realm of supply management: the case of the Korean electronics industry", Supply Chain Management: An International Journal, Vol. 14 No. 2, pp. 138-148.

Loureiro, S.M.C., Dias Sardinha, I.M. and Reijnders, L., (2012). "The effect of corporate social responsibility on consumer satisfaction and perceived value: the case of the automobile industry sector in Portugal", Journal of Cleaner Production, Vol. 37 No., pp. 172-178.

Mamic, I., (2005). "Managing Global Supply Chain: The Sports Footwear, Apparel and Retail Sectors", Journal of Business Ethics, Vol. 59 No. 1-2, pp. 81-100.

Mares, R., (2010). "The limits of supply chain responsibility: a critical analysis of corporate responsibility instruments", Nordic Journal of International Law, Vol. 79 No. 2, pp. 193-244.

Mentzer, J.T., Dewitt, W., Min, S., Nix, N.W., Smith, C.D. and Zacharia, Z.G., (2001). "Defining Supply Chain Management", Journal of Business Logistics, Vol. 22 No. 2, pp. 1-25.

Pagell, M. and Wu, Z., (2009). "Building a more complete theory of sustainable supply chain management using case studies of 10 examplars", Journal of Supply Chain Management, Vol. 45 No. 2, pp. 37-56.

Perry, P. and Towers, N., (2013). "Conceptual framework development: CSR implementation in fashion supply chains", International Journal of Physical Distribution \& Logistics Management, Vol. 43 No. 5/6, pp. 478-501.

Porter, M.E., (1996). "What Is Strategy?", Harvard Business Review, Vol. 74 No. 6, pp. 6178.

Porter, M.E. and Kramer, M.R., (2011). "Creating Shared Value", Harvard Business Review, Vol. 73 No. 5, pp. 62-77.

Raiborn, C.A. and Payne, D., (1990). "Corporate Codes of Conduct: A Collective Conscience and Continuum", Journal of Business Ethics, Vol. 9 No. 11, pp. 879-889.

Reuter, C., Foerstl, K., Hartmann, E. and Blome, C., (2010). "Sustainable global supplier management: the role of dynamic capabilities in achieving competitive advantage", Journal of Supply Chain Management, Vol. 46 No. 2, pp. 45-63.

Reuter, C., Goebel, P. and Foerstl, K., (2012). "The impact of stakeholder orientation on sustainability and cost prevalence in supplier selection decisions", Journal of Purchasing \& Supply Management, Vol. 18 No. 4, pp. 270-281.

Rotaru, K., Churilov, L. and Filtman, A., (2014). "Can critical realism enable a journey from description to understanding in operations and supply chain management?", Supply Chain Management: An International Journal, Vol. 19 No. 2, pp. 117-125.

Soosay, C., Fearne, A. and Dent, B., (2012). "Sustainable value chain analysis - a case study of Oxford Landing from 'vine to dine"', Supply Chain Management: An International Journal, Vol. 17 No. 1, pp. 68-77. 
Spence, L. and Bourlakis, M., (2009). "The evolution from corporate social responsibility to supply chain responsibility: the case of Waitrose", Supply Chain Management: An International Journal, Vol. 14 No. 4, pp. 291-302.

Strand, R., (2009). "Corporate Responsibility in Scandinavian Supply Chains", Journal of Business Ethics, Vol. 85 No. 1, pp. 179-185.

Svensson, G., (2013). "Processes of substantiations and contributions through theory building towards theory in business research", European Business Review, Vol. 25 No. 5, pp. 466-480.

Svensson, G. and Bååth, H., (2008). "Supply chain management ethics: conceptual framework and illustration", Supply Chain Management: An International Journal, Vol. 13 No. 6, pp. 398-405.

Svensson, G. and Wagner, B., (2012). "Implementation of a sustainable business cycle: the case of a Swedish dairy producer", Supply Chain Management: An International Journal, Vol. 17 No. 1, pp. 93-97.

Teegen, H., Doh, J.P. and Vachani, S., (2004). "The importance of nongovernmental organizations (NGOs) in global governance and value creation: an international business research agenda", Journal of International Business Studies, Vol. 35 No. 6, pp. 463-483.

Walker, H. and Jones, N., (2012). "Sustainable supply chain management across the UK private sector", Supply Chain Management: An International Journal, Vol. 17 No. 1, pp. 15-28.

Walker, K. and Laplume, A., (2014). "Sustainability fellowships: the potential for collective stakeholder influence", European Business Review, Vol. 26 No. 2, pp. 149-168.

Wced, (1987). World Commission on Environment and Development, Oxford University Press, Oxford, UK.

Winter, M. and Knemeyer, M., (2013). "Exploring the integration of sustainability and supply chain management: Current state and opportunities for future inquiry", International Journal of Physical Distribution \& Logistics Management, Vol. 43 No. 1, pp. 18-38.

Wisner, J.D. and Tan, K.C., (2000). "Supply Chain Management and Its Impact on Purchasing", The Journal of Supply Chain Management, Vol. 36 No. 3, pp. 33-42.

Womack, J. and Jones, D., (1996). Lean thinking: banish waste and create wealth in your corporation, Simon and Schluster, New York, NY.

Worthington, I., Ram, M., Boyal, H. and Shah, M., (2008). "Researching the Drivers of Socially Responsible Purchasing: A Cross-National Study of Supplier Diversity Initiatives", Journal of Business Ethics, Vol. 79 No. 3, pp. 319-331.

Young, I.M., (2004). "Responsibility and Global Labor Justice", The Journal of Political Philosophy, Vol. 12 No. 4, pp. 365-388. 
Figure 1: A Balance Model towards Theoretical Business Sustainability to Leverage the Inferior Side to Enhance Performance

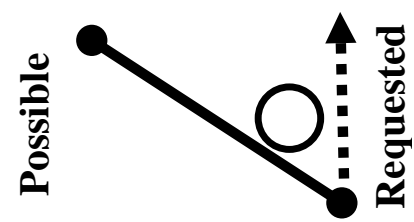

(A)

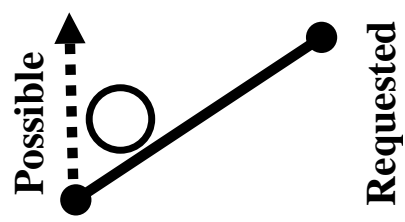

(B)

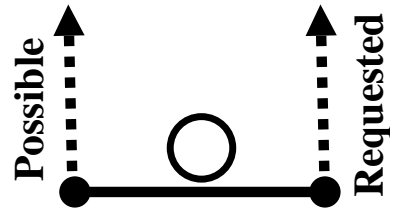

(C) 